компонентами: мотивационно-ценностным, когнитивно-смысловым, субъектнодеятельностного.

Ключевые слова: физическая терапия, готовность, профрессиональная деятельность, компоненты готовности, структура готовности, физкультурнооздоровительные технологии.

\title{
SUMMARY
}

Bespalova Oksana. Concept and structural components of readiness of future bachelors on physical therapy, ergotherapy to the application of physical culture and health technologies.

An important task of the system of higher education is the formation of the readiness of specialists in physical therapy and ergotherapy to use physical culture and health technologies in future professional activities. Despite a large number of scientific developments and publications, the issue of the readiness of future specialists in physiotherapy and ergotherapy to implement physical education and health technologies in future professional activities is not adequately reflected. Therefore, the purpose of the article was to determine the nature and structure of the readiness of specialists in physiotherapy and ergotherapy to apply the technologies of physical education and health in future professional activities. To solve this problem, the following research methods were chosen: analytical analysis of scientific and methodological literature, generalization of research results of individual authors. The article presents the interpretation of the concept of "readiness" in various scientific aspects. Accordingly, scientific research and research findings have shown that the formation of the readiness of a specialist in physical therapy and ergotherapy for future professional activities is a complex multidimensional problem. The essence of the readiness of future bachelors from physical therapy and ergotherapy to the introduction of physical culture and health technologies should be considered as an integrative quality of the individual, characterized by his aspirations and efforts to professional self-realization in the process of labor activity. The structure of the readiness of future specialists for the implementation of physical culture and health technologies is presented by interrelated and interrelated components, including: motivationalvalue, cognitive-content, subject-activity.

Key words: physical therapy, readiness, professional activity, readiness components, readiness structure, physical culture and health technologies.

УДК 316.614 (09)

Любов Прядко

Сумський державний педагогічний

університет імені А. С. Макаренка

ORCID ID 0000-0002-7168-4601

DOI 10.24139/2312-5993/2019.05/280-290

\section{ВИКОРИСТАННЯ ДОСВІДУ А. МАКАРЕНКА В ПОПЕРЕДЖЕННІ ПОРУШЕНЬ ПОВЕДІНКИ ДІТЕЙ З ОСОБЛИВИМИ ОСВІТНІМИ ПОТРЕБАМИ}

у статті розкрито та обгрунтовано основні положення попередження подолання порушень поведінки в системі А. Макаренка. Метою статті є розкриття використання досвіду А. Макаренка в попередженні порущень поведінки дітей, які мають особливі освітні потреби. Зокрема, особлива увага приділена базовим 
допомінним факторам подолання порушень поведінки. Автором зазначено, що практичне значення окреслених положень $\epsilon$ важливим для педагогів загальної та спеціальної освіти в корекційно-освітньому процесі. Це дало можливість узагальнити наукові факти, обгрунтувати та висвітлити основні положення системи А. Макаренка у світлі попередження порушень поведінки у закладах як спеціальної, так і інклюзивної освіти.

Ключові слова: інклюзивна освіта, діти з особливими освітніми потребами, попередження порушення поведінки.

Постановка проблеми. Відомі видатні педагоги, майстри своєї справи замислювалися над тим, як підготувати підростаюче покоління до житя, як сформувати майбутнє своєї країни, нації. Відповідно, кожен із них зробив свій значний внесок у розвиток суспільства взагалі та цивілізації зокрема. Саме це $\epsilon$ спільним у педагогічній діяльності педагогів та мислителів. Кого 6 ми не взяли до уваги з видатних особистостей, які залишили помітний слід у скарбниці світових надбань, то всі вони замислювалися над тим, як ефективно вплинути на підростаюче покоління за своєю особливою системою, як поринути в дитячий світ і знайти там щось особливе, на чому можна було би побудувати освітньо-виховний маршрут розвитку людини. Дуже яскравою особистістю на цьому тлі залишається А. Макаренко. Він у своїй діяльності керувався реальними складними сферами у розвитку дитини - навичками спілкування та культури поведінки, тобто тим, що ми сьогодні називаємо базовими вміннями особистості для того, щоб вижити в сучасному швидкозмінному світі.

Педагогічна діяльність нашого земляка А. Макаренка $\epsilon$ золотою скарбницею світових досягнень у сфері виховання підростаючого покоління. Він $€$ класиком педагогіки з одного боку і новатором - 3 іншого. Якщо зануритися глибше в його педагогічну діяльність, то всі його педагогічні методи та принципи спрямовані на формування вмінь і навичок життєвої компетенції, які сьогодні $є$ ключовими у світовій педагогіці. Це пояснюється тим, що в Антона Семеновича $€$ те, що не вмирає у будь-якій виховній системі, і завжди буде на часі, - глибока повага та увага до людської особистості, яка зростає, та обережний підхід до природи дитячої душі. Його досвід налічує дуже багато дітей та підлітків із порушенням поведінки, патологічними проявами рис характеру, специфічними особливостями пізнавальної діяльності, але ніде в його спадщині ми не зустрінемо навіть натяку на те, що це діти не такі, що вони мають порушення, що їх треба ізолювати. Як мудрий педагог, А. Макаренко вважав виправлення таких дітей справою всього педагогічного колективу, адже він дійсно займався корекційною роботою.

Досвід Великого педагога не втратив свого значення і сьогодні. 
Червоною ниткою в його спадщині проходить віра в дитину, її випереджальну функцію в розвитку дитини, підлітка, юнака. Він постійно підкреслював, що справжня педагогіка живиться самим життям. Говорячи про результати своєї роботи, він зазначає, це «диво» створює вся атмосфера життя.

Перспективи розвитку дитини залежали завжди від сформованості ії адекватної поведінки. Сформувати в дитини адекватну поведінку сформувати ї̈ долю. Завжди поведінка дитини обумовлюється тим середовищем, у якому вона перебуває й перебувала. Вона, як і будь-який процес, має історію свого формування. Коли дитина з особливими освітніми потребами потрапляє в освітнє середовище, то вона приносить із собою весь досвід попереднього спілкування, чим нерідко і провокує конфлікти.

У самому простому розумінні поведінка - це дія або ланцюг подій. У кожної поведінки є історія формування. Поведінка формується під впливом зовнішнього середовища. Деякі стимули можуть провокувати або підтримувати поведінку протягом тривалого часу. У зв'язку з цим існує різноманітність варіантів поведінки. Те, що одна людина вважає правильним, інша може вважати абсурдним. Реакція дитини є мимовільною. Те, що нам здається продуманим, передбаченим, з боку дитини може бути проявом імпульсивності або дисбалансу в роботі нервової системи. Таким чином, прояви поведінки можуть мати як біологічний, так і середовищний характер. У світлі зазначеного дуже цінним є сьогодні досвід А. Макаренка.

Аналіз актуальних досліджень. Педагогічна спадщина А. Макаренка широко досліджувалася й досліджується вітчизняними та зарубіжними вченими (Н. Абашкіна, О. Алєко, С. Вітвицька, Г.Жураковський, І. Зязюн, М. Ніжинський, С. Карпенчук, Л. Прядко, А. Сбруєва, В. Синьов, В. Сухомлинський, М. Ярмаченко та ін.), проте скільки б не вивчали його досвід, завжди знайдеться щось надзвичайне та цікаве для вивчення в подоланні порушень поведінки.

Дослідниця С. Вітвицька визначає інноваційність новаторського підходу А. Макаренка у створенні нових умов життя для вихованців: соціокультурне розвивальне середовище, взаємопідтримку в колективі як набуття соціального досвіду і моральності.

Мета статті - розкриття особливостей використання досвіду А. Макаренка в попередженні порушень поведінки дітей, які мають особливі освітні потреби. Особливу увагу слід приділити базовим та додатковим аспектам попереджень порушення поведінки.

Методи дослідження. Для розкриття використання досвіду А. Макаренка в попередженні порушень поведінки дітей, які мають особливі 
освітні потреби, використовувались аналіз і синтез, індукція й дедукція, абстрагування, моделювання. Це дало можливість узагальнити наукові факти, обґрунтувати та висвітлити базові та додаткові аспекти попередження порушень поведінки дітей із особливими освітніми потребами.

Виклад основного матеріалу. Проблема порушення поведінки в сучасних дітей і підлітків $€$ однією з найпоширеніших скарг учителів та батьків. Поширеність порушень поведінки коливається в межах від 12 \% до 25 \% від загальної кількості дитячої популяції. У хлопчиків порушення поведінки спостерігаються у 85 \%, у дівчаток 15 \% відповідно).

Зауважимо, що порушення поведінки - це відхилення від прийнятих у даному суспільстві соціальних і етичних норм, дії або вчинки, що суперечать нормам загальноприйнятої моралі і включають: агресивність деструктивної (руйнівної) і асоціальної (направленої проти колективу) спрямованості 3 картиною, що повторюється, дезадаптації (порушення пристосовності) поведінки.

Порушення поведінки найчастіше виникає в дітей із особливими освітніми потребами, які мають завищену самооцінку, і, відповідно, підвищене відчуття власної гідності. Для всіх дітей з типовим розвитком притаманна одночасна активність і енергійність. Частіше за все невротично обумовлена впертість завжди супроводжується відчуттям провини і хвилювань з приводу власної поведінки. Вона має мимовільний, хворобливий характер, $\epsilon$ проявом функціонального розладу вищої нервової діяльності під впливом тривало діючого і невирішеного для дитини емоційного стресу (Синьов, 1998; Ярмаченко, 1998).

Перед тим, як визначити базові та додаткові фактори попереджень порушення поведінки в дітей із особливими освітніми потребами, визначимо механізми порушення поведінки, які зустрічаються найчастіше, відповідно до основних процесів нейродинаміки: збудження і гальмування.

Підвищення процесу збудження під впливом стресу проявляється неспокоєм, нетерпеливістю, мимовільним пришвидшенням мовлення і мислення, нестійкістю уваги, непосидючістю. Чим більше зауважень отримує дитина, тим більше вона збуджується.

Під час переваги процесу гальмування перестають виявляти дію звичайні подразники й потрібна додаткова стимуляція для спонукання дитини виконати ту чи іншу дію. Дитина ніби спить на ходу, все робить надзвичайно повільно, в'яло їсть, повільно одягається, постійно відволікається. Часто педагоги такі прояви сприймають як виклик, упертість, i тому починають кричати, навіть погрожувати. Це дає короткочасний ефект 
типу поштовху, але з більш вираженим гальмуванням.

Упертість може бути обумовлена загальною збудливістю й нестійкістю уваги, коли дитина не може бути послідовною у сприйманні великої кількості порад і обмежень з боку дорослих. Виправдати їх вона не в змозі. Підвищення активності процесу збудження більше характерно для дітей із холеричним темпераментом, коли вони ніби перетворюються «двічі в холериків» - надмірно швидких і непосидючих.

Звертаючись до спадщини Великого педагога, визначимо базові та допоміжні фактори, які сприяють попередженню порушення поведінки дітей із особливими освітніми потребами. До базових факторів можемо віднести:

1) формування функції гальмування поведінки;

2) формування здатності орієнтуватися в навколишньому світі;

3) формування ввічливості;

4) виховання звички уступити товаришу;

5) організація захищеності кожної дитини,

6) віра в можливості дитини діяти адекватно до ситуації;

7) формування звички долати тривалі труднощі.

До допоміжних факторів можемо віднести:

1) використання прийому «вчинок по секрету»;

2) авансована повага.

Опишемо їх у зазначеній послідовності.

1. Формування функції гальмування поведінки.

Важливою ознакою сформованості зрілості людини $€$ звичка до гальмування своєї поведінки. Гальмувати себе - найскладніша справа, особливо в дитинстві, воно не приходить у результаті фізіологічних змін вищої нервової діяльності, воно може бути тільки вихованим. На жаль, у сьогоднішньому суспільстві на цю звичку не звертається належна увага. На думку відомого психіатра В. Гарбузова, у дітей із нормативним розвитком ця звичка має бути сформована вже до шестирічного віку. А. Макаренко цьому надавав виключного значення. Він зазначав, що «... постійно у вихованців треба розвивати вміння бути стриманими в рухах, у словах, у криках. Треба вимагати дотримання тиші там, де вона потрібна, треба відучувати вихованців від непотрібного крику, непомірно-розв'язного сміху і руху» (Макаренко, 1972, с. 363).

2. Формування здатності орієнтуватися в навколишньому світі.

Дітям із особливими освітніми потребами дуже важко самостійно усвідомити й узагальнити відносини і поведінкові акти, що включені в спеціально організовану педагогом діяльність. Звідси виникає дуже суттєва 
проблема навчити дітей виділяти, осмислювати й узагальнювати ті моральні і правові норми, що підлягають засвоєнню. Досить важливо, щоб засвоюючи правила поведінки в різних ситуаціях і видах діяльності, діти були активними й мали можливість виявити емоційно-особистісну зацікавленість у здійсненні правильного вчинку. Ця здатність передбачає наявність уміння відчувати те, що відбувається навколо в оточенні, можливість побачити те, що робиться в інших кімнатах, відчути тон життя, тон дня. Без сформованості цієї навички неможливо здійснити будь-яку діяльність. Це вміння виховується дуже важкою працею.

3. Формування ввічливості.

Особливою формою гальмування $\epsilon$ ввічливість, яку можна настирливо рекомендувати вихованцям, і при будь-якому зручному випадку і вимагати ії дотримання. У вихованні А. Макаренко вбачав не лише виховання правильне, розумне ставлення до питань поведінки, але й виховання правильних звичок. У його трактуванні це звички, коли ми діємо так, бо інакше ми просто не можемо. У зв'язку з цим виховання позитивних звичок поведінки $€$ складнішим, ніж виховання свідомості. Для формування окреслених навичок дуже важливо і самому педагогу бути зразком для наслідування, тобто самому мати хороші манери, робити вчинки, бути різносторонньо освіченою людиною. Він повинен з повагою ставитися до дітей; по можливості всіляко уникати конфліктних ситуацій, або ж уміти тактовно їх вирішувати; вислухати всі питання (Прядко, 2013).

4. Виховання звички уступити товаришу.

Ця звичка $€$ особливо важливим фактором виховання у XXI столітті, оскільки для сучасних дітей характерна підвищена імпульсивність, загострене відчуття справедливості, і, водночас, відсутність почуття обов'язку. І цю звичку можна сформувати виключно після оволодіння вмінням стримувати себе. Сучасному педагогу необхідно враховувати природу конфлікту і самому обрати відповідний стиль поведінки, і завжди знати обставини дитячого життя.

\section{5. Організація захищеності кожної дитини.}

Кожна дитина з особливими освітніми потребами потребує відчуття захищеності для того, щоб розкрились їі найкращі якості та не мали змоги проявитись і закріпитись негативні. Жоден вихованець, яким би він не був малим і слабким або новим у колективі, не повинен відчувати свого уособлення або незахищеності. У колективі існує міцний закон, що ніхто не лише не має права, але й не має можливості безкарно знущатися, чинити насильство над найслабшим членом колективу. Мовою сучасної науки - це відсутність булінгу та його профілактика. 
6. Віра в можливості дитини.

Віра в дитину є важливими принципом формування високоморальної особистості. «Людина погана тільки тому, що вона знаходиться в поганій соціальній структурі, у незадовільних умовах. Я був свідком того, коли найскладніші хлопчики, яких виганяли з усіх шкіл, вважали за дезорганізаторів, в умовах нормальної педагогічної громади майже на другий день ставали гарними, дуже талановитими, здібними, мали бажання іти вперед. Уміти побачити гарне в людині не кожен зможе. Гарне в людині зажди треба проектувати, і педагог це зобов'язаний робити. Він зобов'язаний підходити до дитини з оптимістичною гіпотезою, хай навіть з деяким ризиком помилитися» (Макаренко, 1972, с. 82).

7. Формування звички долати тривалі труднощі.

Формування звички долати тривалі труднощі передбачає здатність дитини з особливими освітніми потребами не зупинятися перед реальними труднощами, а йти до кінцевої мети. 3 цією метою педагогу слід конкретизувати мету діяльності та перспективи на кожному етапі роботи; використовувати різноманітні засоби, обов'язково дотримуватися принципу доступності на кожному етапі виконання завдання. Створення позитивного емоційного фону допомогає дітям у подоланні труднощів, які з'являються раптово, несподівано.

«Скільки $б$ не створювали правильних уявлень про те, що треба робити, але якщо ви не виховали звичку долати тривалі труднощі, я маю право сказати, що ви нічого не виховали. Звичка долати тривалі труднощі $\epsilon$ важливим показником соціалізації. Скільки 6 не створювали правильних уявлень про те, що треба робити, але якщо ви не виховали звичку долати тривалі труднощі, я маю право сказати, що ви нічого не виховали» (Макаренко, 1972, с. 64). Звичка долати тривалі труднощі $€$ важливим показником соціалізації.

До допоміжних факторів можемо віднести такі:

\section{1. «Вчинок по секрету».}

Основним завданням $€$ не лише виховування в собі правильного, розумного ставлення до питань поведінки, але й також виховування правильних звичок. Для цього А. Макаренко використовував вчинок посекрету: «це дуже точна перевірка свідомості, як людина поводить себе тоді, коли ніхто не бачить, не чує, не перевіряє, а особливо виражається у спорах і лайках. Як часто діти затівають лайку тому, що в них відсутня здатність до гальмування. Цей прийом заслуговує на особливу увагу. Це все виходить $з$ того, що людина завжди усвідомлює, як треба чинити і тому наше завдання 
полягає в тому, щоб виховати в собі правильне, розумне ставлення до питань поведінки і чинити так тому, що інакше робити не можна. Виховання цих звичок складніше, ніж виховання свідомості, оскільки тут мається на увазі формування правильних звичок. Важливим показником сформованості звичок $\epsilon$ здатність здійснювати вчинки «по секрету», коли ніхто не бачить, не чує, не перевіряє. Адже легко навчити людину чинити правильну у присутності когось стороннього, а ось навчити поступати правильно, коли ніхто не бачить, не чує і не знає, - дуже нелегке завдання. Для формування адекватної поведінки велике значення має виховання таких якостей, як терпіння, уміння долати труднощі, психологічно правильно долати перешкоди.

\section{2. Авансована повага.}

Кожній людині важлива довіра. Вона допомагає прокладати мости у стосунках, створювати зв'язки, рости у власних очах, хоча нею треба користуватися дуже обережно. Під час організації виховного процесу педагог повинен володіти прогностичними вміннями, передбачати майбутнє дитини, запобігати появі негативних звичок, поважати дітей, хоча за зовнішніми особистісними ознаками, може бути, і не заслуговує на це. Щоб авансувати повагу - треба дуже гарно знати дітей. Для цього педагогу в першу чергу треба бути спостерігачем і дослідником. Робота вихователя повинна полягати в наступному: передусім вихователь повинен знати склад своїх колективів, повинен знати життя й особливості характеру кожного вихованця, його намагання, сумніви, недоліки та переваги.

Навчання та виховання дітей, які мають особливі освітні потреби, завжди спрямовані на культурний розвиток дитини, адже вищі психічні функції можуть розвиватися лише на основі культурного розвитку дитини. А. Макаренко довів, що всі діти здатні до культурного розвитку, якщо створити для цього відповідні умови. Якщо узагальнити підходи в системі А. Макаренка, то секретом його успіху можна вважати реальну підготовку своїх вихованців до життя. Він намагався створити таку систему, яка $б$ у майбутньому забезпечила колишніх вихованців самостійним, незалежним життям, тобто соціалізувати їх.

Можливо не дуже сучасним здається підхід видатного педагога до наказів та їх виконання. Це стосується тих моментів, коли установлюється певна форма ввічливості і на кожен наказ підлеглий член колективу повинен дати відповідь «Так!» і повторити наказ. Ця форма ввічливості у ділових стосунках надзвичайно важлива, бо вона мобілізує волю, примушує людину відчувати себе зібраною й викликає повагу до справи. 3 іншого боку, таке повторення наказу чи то прохання і проговорювання дає можливість краще 
зрозуміти звернене мовлення, усвідомити завдання і правильно виконати наказ. Таким чином, це допомагає забезпечити зворотній зв'язок із педагогом.

Важливим уроком для нас $є$ висновок Антона Семеновича про те, що гуманізм полягає не в красивих словах і деклараціях, а у відповідальності, повсякденній реальній роботі зі створення нормальних умов для здорового побуту, навчання, праці, освоєння професії, фізичного зростання й духовного росту молодої людини.

Високий темп життя колективу, тісні зв'язки між його членами, відкрите, демократичне обговорення всіх питань на загальних зборах, в інших органах учнівського самоуправління, поступово стають запорукою здорової громадської думки. Періодична заміна активу, рівні вимоги до кожного і обов'язковий звіт за роботу перед колективом стають перешкодою для чванства, зарозумілості, бюрократизму.

Виховання, стверджував А. Макаренко, - процес соціальний... 3 усім складним світом навколишньої дійсності дитина входить у нескінченне число стосунків, кожний з яких обов'язково розвивається, переплітається 3 іншими стосунками, ускладнюється фізичним і моральним ростом самої дитини. Спрямувати цей розвиток і керувати ним - завдання вихователя. Педагог А. Макаренко розглядає виховання як невід'ємну складову процесу життєдіяльності особистості, робить висновок про необхідність педагогічно відповідної організації життя дітей, бачить форму такої організації у виховуючій силі колективі.

Саме на справжньому піклуванні про наших дітей, їх розвиток ми повинні сьогодні перевіряти гуманізм і демократизм керівників закладів освіти, чиновників, учених, педагогічних колективів.

Теорія педагогічного колективу, розроблена і втілена в життя А. Макаренком, і сьогодні допоможе вдосконалити виховну роботу в закладах освіти. Модель учнівського колективу, створена ним, $\epsilon$ неперевершеною. Як би не змінювалися погляди на колектив, але колектив, який виникає на основі спільної діяльності і спільних цілей, чіткої організації життя дітей, має незаперечне значення у становленні дитини як особистості та громадянина.

Новаторський підхід А. Макаренка полягає у створенні для життя вихованців соціокультурного розвивального середовища, яке унеможливить прояви негативних рис, мінімізує прояви попереднього вуличного досвіду. У колективі педагог забезпечить взаємопідтримку і взаємозахищеність, а це є основними аспектами для підтримки високого рівня душевного комфорту. Закон перспективних ліній, паралельної дії, єдність вимог, традиції вселяли у 
вихованців віру в себе та завтрашній день, вони бачили перспективу, порівняно із сучасними дітьми. Така система давала можливість стати кращим уже сьогодні, досягти якісних позитивних змін у своєму становленні.

Неперевершені результати роботи А. Макаренка і сьогодні не можуть залишити людину байдужою: вона стає або прихильником його ідей, або їх противником. Концептуальними засадами педагогіки А. Макаренка виступає ідея гуманізму як єдність принципів природовідповідності та культуровідповідності, педагогічного оптимізму, поваги й вимогливості, що виражається в єднанні мети-ідеї-принципу (Карпенчук, 2014).

Висновки. Таким чином, у надбанні видатного педагога-новатора ми сьогодні можемо знайти ідеї та практичні шляхи для розв'язання важливої проблеми зв'язку особистості й суспільства, не дивлячись на XXI століття. Організувати на цьому ґрунті виховання, у якому створюються умови для розвитку в дітей здатності до вільного вибору і для їх самореалізації в суспільстві та подоланні порушень поведінки. Отже, розібратись у причинах порушення поведінки - значить підібрати ключик до дитини, до її творчої і плідної діяльності. Головним у роботі з такими дітьми - не дивитись на них упередженим поглядом, намагатися захопити їх цікавим завданням та грою. Створювати умови реалізації можливостей, потреб та інтересів.

Перспективи подальших наукових розвідок будуть стосуватися профілактики порушень поведінки дітей із особливими освітніми потребами кожної окремої нозології.

\section{ЛІТЕРАТУРА}

Карпенчук, С. (2014). Педагогічні ідеї А. С. Макаренка: гуманістичні контексти. Нова педагогічна думка, 4 (80), 118-124 (Karpenchuk, S. (2014). Pedagogical ideas of A. S. Makarenko: humanistic contexts. New pedagogical thought, 4 (80), 118-124).

Макаренко, А. С. (1972). Коллектив и воспитание личности. М.: Издательство «Педагогика» (Makarenko, А. S. (1972). Collective and upbringing of the person. M.: Publishing house "Pedagogics").

Прядко, Л. О. (2013). Застосування принципів виховної роботи А. С. Макаренка в теорії та практиці корекційної освіти. Педагогічні науки: теорія, історія, інноваційні технологіï, 3 (29), 199-205 (Priadko, L. O. (2013). An application of the principles of A. S. Makarenko's educational work in the theory and practice of correctional education. Pedagogical sciences: theory, history, innovative technologies, 3 (29), 199-205).

Синьов, В. М. (1998). Вплив творчої спадщини А. Макаренка на розвиток вітчизняної та світової пенітенціарної педагогіки. Педагогіка і психологія, 1, 128-132 (Siniov, V. M. (1998). Influence of A. Makarenko's creative heritage on the development of domestic and world penitentiary pedagogy. Pedagogics and psychology, 1, 128-132).

Ярмаченко, М. Д. (1998). А. Макаренко і світова педагогіка XX ст. Педагогіка $і$ психологія, 1, 5-10 (Yarmachenko, M. D. (1998). A. Makarenko and world pedagogy of the twentieth century. Pedagogy and psychology, 1, 5-10). 


\section{PEЗЮME}

Прядко Любовь. Использование опыта А. Макаренко в предупреждении нарушений поведения детей с особыми образовательными потребностями.

В статье раскрыты и обоснованы основные положения предупреждения нарушений поведения в системе А. Макаренко. Целью статьи является раскрытие использования опыта А. Макаренко в предупреждении нарушений поведения детей, имеющих особые образовательные потребности. В частности, особое внимание уделено базовым и вспомогательным фракторам. Автором отмечено, что практическое значение определенных положений является важным для педагогов общего и специального образования в коррекционно-образовательном процессе. Это дало возможность обобщить научные фракты, обосновать и осветить основные положения системы А. Макаренко в свете предупреждения нарушений поведения как в учреждениях специального, так и инклюзивного образования.

Ключевые слова: инклюзивное образование, дети с особыми образовательными потребностями, предупреждения нарушения поведения.

\section{SUMMARY}

Pryadko Lubov. Use of A. Makarenko's experience in prevention of behavioral disorders of children with special educational needs.

The article reveals and substantiates the main provisions of prevention of the behavioral disorders in A. Makarenko's system, which is relevant for both children with typical development and with special educational needs. The purpose of the article is to reveal the use of experience of A. Makarenko in prevention of behavioral disorders of children with special educational needs. In particular, the main attention is paid to the basic aspects of prevention of behavioral disorders: formation of the inhibition behavior function, the ability to orient in the environment; formation of courtesy; upbringing the habit of giving way to a friend; organization of protection of every child, belief in the child's ability to act adequately to the situation and auxiliary aspects: the use of the admission "act of secrecy", advance of respect. Research methods are analysis and synthesis, induction and deduction, abstraction and modeling. The results of the study indicate the need and effectiveness of the use of these provisions in the theory and practice of modern education, since according to statistics, today every tenth child has problems with behavior for children with typical development and with special educational needs. The author states that the practical significance of the above-mentioned provisions is important for teachers of general and special education in the correctional and educational process for both children with typical development and with special educational needs. This has made it possible to generalize scientific facts, to substantiate and highlight the main provisions of A. Makarenko's system in the light of prevention of behavioral violations both in institutions of special and inclusive education. As a conclusion, it can be noted that the main mechanism of prevention is the ability of the teacher to pick the key to the child, not to look at him/her with a biased view and an attempt to influence him/her by his authority. Prospects for further scientific research will address prevention of behavioral abnormalities in each individual nosology for both children with typical development and with special educational needs.

Key words: inclusive education, children with special educational needs, prevention, behavioral disorders. 